\title{
BRANDING PRIVATE HIGHER EDUCATION INSTITUTIONS IN SOUTH AFRICA THROUGH THE EVALUATION OF CURRENT BRANDING MODELS
}

\author{
Alan Bird ${ }^{1}$ \\ Cape Town, South Africa, 7535 \\ Virimai Mugobo \\ Department of Retail Business Management \\ Cape Town, South Africa, 7535 \\ ${ }^{l}$ Faculty of Business and Management Sciences \\ Cape Peninsula University of Technology
}

\begin{abstract}
The current Private Higher Education Institution (PHEI) landscape in South Africa is developing at a rapid rate, with over ninety private tertiary institutions, registered with the Council for Higher Education (CHE). However, stakeholder perceptions of these PHEIs are generally negative, largely as a result of the negative perceptions of the qualification, obtained from the private institutions by both parents and students, and questions around the sustainability of the institutions in the long run. Media reports, lack of Department of Education (DHET) support and funding, as well as minimum, if any, marketing and advertising from the PHEI are factors, cited for these firmly entrenched perceptions from the general public. The article was driven by both current and emerging branding models as a benchmark for value-added branding of PHEIs in South Africa. International markets, in countries such as Singapore, Malaysia, India and Brazil are included; not as a comparative study, but more as a review of literature on how tertiary education is branded in the private sector in these countries. In addition, developing countries and emerging markets needed to be taken into consideration in the light of their experience in sustaining private education entities. The subsequent investigation of these models proved invaluable in respect of providing similarities and, in some instances, huge differences, which contributed to the establishment of a generic value-added branding model critical for sustaining PHEIs in South Africa. The knowledge of which dimensions the branding of a PHEI should focus on to nullify the negative perceptions associated with a PHEI is paramount.
\end{abstract}

Keywords: Sustainability of PHEIs, negative perceptions, dimensions of branding, branding models.

DOI: $10.21303 / 2504-5571.2021 .001841$

\section{Introduction}

Demand for tertiary education in South Africa has led to new markets and more and more local private education institutions being established. The concept of PHEIs and the branding of these institutions play a critical role in the acceptance of PHEI qualifications by students, parents, sponsors and industry in a volatile and dynamic changing education field in South Africa [1].

Even though PHEIs can trace their existence back to the post-war industrial boom of the 1950s and 1960s, world-wide, as well as in South Africa [2], it was only during the late 1980s and early 1990s that PHEIs began to grow and develop in South Africa. With the new dispensation, led by an African National Congress (ANC) government, taking over in 1994, the new government established the National Commission on Higher Education [3]. In addition, the adoption of the National Qualifications Framework (NQF) in 1995 saw the establishment and growth of PHEIs throughout South Africa [4].

Most of the larger PHEIs have made use of marketing opportunities to try and assure their future and sustainability, focusing more on the needs of the $21^{\text {st }}$ century Higher Education (HE) student in South Africa. Smaller PHEIs have limited budgets and thus gain far less marketing opportunities. These smaller PHEIS (those with less than 250 students) have no marketing or branding models and rely more on word-of-mouth advertising. The accreditation of these smaller PHEIs is based on their ability to develop a curriculum course that is then licensed and accredited by the Department of Higher Education [2]. Thus, the private higher education landscape in South Africa consists of larger, sustainable colleges and smaller (in numbers) colleges in a highly competitive market. 
Froneman [4] maintains that the changing education landscape for public universities, also known as traditional universities in South Africa, has had a vast impact on the rise of PHEIs. This has been partly due to the number of school leavers in South Africa, seeking entrance to higher education greatly increasing year-on-year. Froneman [5] postulates that higher education in South Africa is experiencing an unrelenting pressure to extend study opportunities to these school leavers. This will ultimately result in increased applications and overcrowding at public universities in South Africa [6], allowing for opportunities for PHEIs to find their niche in the complex field of higher education.

$21^{\text {st }}$ century higher education innovations, such as blended learning approaches and technology-based higher education, have become branding drivers in that they promote the modern day student's experience as well as allow an educational institution to deliver more individual attention to students because of smaller enrolments. In addition, academic freedom of thought amongst students in a smaller learning environment is becoming more evident [7].

Despite the growing boom of private higher education in South Africa, most of the larger and more prominent private institutions rely on their corporate image and web-site branding to remain successful and profitable [8]. Branding and brand building amongst most of the PHEIs in South Africa has relied on the 'names' of these PHEIs in the market place, as well as their ability to adhere to quality standards and quality qualifications that both students and workplaces (industry) demand [9].

The 90 PHEIs in South Africa today have over 120000 full-time registered students [2], and produce a wide variety of qualifications, need to adhere to community and industry standards and expectations. Badenhorst [1] notes that a $3^{\text {rd }}$ of all higher education enrolments is at private institutions. Froneman [5] states that PHEIs provide skills, needed for the $21^{\text {st }}$ century economy. He argues further that market forces have a great influence on private higher education. However, despite this phenomenal growth of PHEIs in South Africa, limited marketing of the institutions could potentially derail their sustainability objectives [10]. Branding amongst PHEIs in South Africa has relied mainly on their 'name' in the market place with some limited media advertising and this points out to a lack of coherence as well as a unified branding framework.

Traditional media and advertising have provided limited exposure of private education providers to the general public. Thus, the common ground for all PHEIs is that these institutions need to market themselves profusely [11].

The Higher Education Act 1997 (Act 101 of 1997) facilitated the establishment of PHEIs, and brought control and legislation to the growing and developing market of private tertiary education. The act makes specific reference to the control and registration of PHEIs with the following provisos:

- Private institutions must offer quality education;

- The public must be protected against unscrupulous and exploitative operators;

- Students must obtain qualifications that are aligned with the Higher Education Qualifications Framework (HEQF), and registered with the National Qualifications Framework (NQF);

- The education system should meet the goals of transforming South Africa in accordance with government policy and legislation; and

- Private institutions must comply with the Higher Education Act (Act 101 of 1997) (mentioned above)

In addition to the challenges currently facing most private higher institutions, such as negative image, absence of adequate funding as well as overcrowding of students, these institutions must always comply with the conditions in the legislation, governing their operations. Thus, PHEIs need to find their niche in the complex field of higher education.

A solution is required to address current and future perceptions of PHEIs, and to create a foundation for the branding of PHEIs in an increasingly dynamic and competitive market environment in South Africa.

The aim of the study will be to firstly, assess the current state of PHEIs in South Africa, highlighting both strengths and weaknesses and then to use these concepts as well as prominent theorists to formulate a generic value-added branding model. 


\section{Materials and methods - how the study was conducted.}

The research methodology, adopted for this article, is survey data from 14 participants, used to describe and explain the status of the phenomena as well as to collect information about their perceptions of PHEIs.

Branding of PHEIs forms the conclusion to this article, in that strengths and weaknesses are documented around these institutions, and their sustainability will be assured with current branding tools and techniques. Literature, forthcoming on current branding models and practical application thereof, is from Keller [12] and Aaker's [13] - two of the foremost experts on application of these branding models.

Aaker's model [13] consists of a framework that creates and maintains brand equity. Aaker [14] maintains that this brand equity model can provide value to both the organisation and the consumer. Aaker's model groups the brand equity (assets) into four dimensions: brand awareness/perceived quality/brand associations and brand loyalty. Aaker [14] maintains that these dimensions underlie brand equity and takes it further by illustrating in his model how each dimension can create value. This value is then placed in two groups 1) value to customers and 2) value to the organisation.

In support of Aaker's Brand Equity model, Keller [12] places emphasis on one of the dimensions, namely perceived quality, a simplistic concept relative to an education institution's programmes that could provide an argument for inclusion in a value-added branding model.

Aligned with Aaker's model is Keller's consumer-based brand equity (CBBE) model [12] a more prominent and widely accepted model which builds, measures and manages brand equity. Differentiation between the two models occurs in contrasting Aaker's dimensions against Keller's four sequential steps 1) brand identity; 2) brand meaning; 3) brand response and 4) brand relationships. In Keller's CBBE model, the sequential steps apply to brand building blocks, which collectively make up the brand equity pyramid. Keller, in the model, shows how brand equity is created by reaching the pinnacle of this brand equity pyramid (see Fig. 1).

The brand value that all PHEI's collectively offer its stakeholders can be measured by the brand equity, which refers to the perceived value, associated with a brand by a specific target market [15]. This brand equity is based on the value of the PHEI as an institution, as well as its qualifications in the marketplace. The effectiveness of the branding of the PHEI will be determined by this brand equity - the outcome of the value-added model. This brand offering consists of a value proposition, which provides the benefits, offered by one specific brand over another [16].

In order to execute a reasonable assessment of the current standing of PHEIs in South Africa, various stakeholders with an interest in PHEIs were interviewed for this research article between the period June 2018 and May 2020. The purpose of Table 1 would be then to provide areas of branding that can be incorporated into a model based on the strengths and weaknesses of current branding models discussed. The stakeholders comprised of students (currently studying at a PHEI); parents (invariably the ones who settle the tuition fees); sponsors (who sponsor student's fees privately or from a corporate) and corporate human resources (HR) practitioners (who employ graduates from PHEIs). The stakeholders were interviewed on aspects, such as their awareness of different PHEIs; whether they were aware of performance of these PHEIs (academic success being one of the indicators); the benefits/ strengths of PHEIs and, from a corporate placement perspective, whether they produced employable graduates.

\section{Results of the study}

Table 1, below, highlights the percentages of stakeholders relative to the dimensions given, pertaining to the perceptions of PHEIs in South Africa.

Table 1 above indicates 4 different groups of stakeholders and their perceptions of PHEIs in South Africa. The first group, students, is registered with a private college and studying either a Batchelor of Commerce (Bcom), Batcher of Arts (BA) or Batchelor of Laws (BLaw) degree. 14 students were interviewed, of which the majority ( $82 \%$ ) showed high perceptual awareness of different PHEIs. This would be attributed to either contact with a marketing representative of a private college during their final school years or social media posts they were aware of. This indicates that 
the majority of students are acutely aware of the institutions they would like to study at and would have an overriding say in their higher education study direction.

Table 1

South African stakeholder perception of PHEIs

\begin{tabular}{ccccc}
\hline PHEIs stakeholders & $\begin{array}{c}\text { Awareness of different } \\
\text { PHEIs }\end{array}$ & Performance of PHEIs & $\begin{array}{c}\text { Benefits } \\
\text { (Attributes) of PHEIs }\end{array}$ & $\begin{array}{c}\text { Sustainability of } \\
\text { PHEIs (brand equity) }\end{array}$ \\
\hline Students & $82 \%$ & $88 \%$ & $76 \%$ & $54 \%$ \\
Parents (account payers) & $53 \%$ & $86 \%$ & $45 \%$ & $88 \%$ \\
Sponsors & $30 \%$ & $30 \%$ & $30 \%$ & $30 \%$ \\
$\begin{array}{c}\text { Corporate HR practi- } \\
\text { tioners }\end{array}$ & $45 \%$ & $40 \%$ & $38 \%$ & $38 \%$
\end{tabular}

Source: Authors own sources (taken from the research study)

Parents, who are invariably the account payers, show a moderate awareness (53\%) of the different PHEIs, mainly concerned with the concept of private vs public tertiary institutions rather than any one specific PHEI. Traditionalism and the alma mater concept of which university invariably the father attended, play a role in the awareness or lack of awareness of different type of PHEIs.

Sponsors, albeit, private or corporate, finance the student's study fees, and are showing a low $(30 \%)$ response rate to their understanding of different PHEIs. This could be attributed to the fact that sponsors are more interested in a study direction than any specific higher education institution. For example, if a Law firm is sponsoring an intern, they would finance a Batchelor of Laws degree (BLaws) and leave the choice of university to the student.

Corporate HR practitioners, have a perceptual awareness of different types of PHEIs only from a perspective of employing graduates from any one higher education institution. Thus, the moderate to low (45\%) awareness of different PHEIs is attributed to the fact that corporate HR practitioners are more focused on the National Qualifications Framework (NQF) that aligns a qualification with a particular level than any one PHEI. For example, a 4-year Batchelor of Laws (BLaws) degree will align with NQF level 8, irrespective of from which institution the student obtained their qualification - as long as the higher education institution is accredited and registered with the Department of Education (DHET).

Of the students interviewed, the performance of the PHEIs showed a high response of $88 \%$ to any performance indicators asked. Invariably, the performance indicators centered on academic success and percentage pass rates. The majority of PHEIs in South Africa uses these indicators as part of its marketing toolkit, and advertises in both traditional and on social media, high pass rates - thus students were made aware of these indicators. From a student perspective, these performance indicators are part of what is expected from a PHEI, with smaller classes and more individual attention than a public university, thus students are very susceptible and attracted to percentage pass rates.

Parents also showed a high (86\%) awareness of performance indicators as higher education studies for their children are more about academic success than what a student will experience in terms of university life, sport or cultural happenings on campus.

Sponsors show a low $(30 \%)$ response rate to performance indicators of a PHEI as their interest is more in their prodigies' success than the institution success. As indicated above, they have left the choice of institution to the individual student.

Corporate HR practitioners showed a low (42\%) response rate to the performance indicators of a PHEI, indicating that graduate placement of a student is based on the NQF level obtained and not the performance indicator of the study institution.

Students indicated a moderately high $(76 \%)$ response rate to the attributes or benefits of a PHEI. PHEIs would provide smaller classes and additional academic support as attributes and would not be able to have benefits, such as superior sport facilities, campus accommodation or indigenous cultural groups. However, albeit limited campus life attributes, students will still expect 
PHEIs to demonstrate or advertise their attributes that provides strong and positive identity to the higher education institution they are studying at.

Parents (45\%), sponsors (30\%) and corporate HR practitioners (38\%) all show low response rates to attributes of PHEIs as their interest lies in academic success of their vested interest in the student.

Students showed a moderate $(54 \%)$ response rate to the sustainability of the PHEI. Even though PHEIs in South Africa are in a growth stage, many of the larger PHEIs (from a student enrolment perspective) have been in existence for more than twenty years, indicating sustainability and longevity of the higher education institutions.

Parents' response rate of $88 \%$ (high) indicates more awareness of the so called "fly by night" institutions, and from a financial perspective, they would need to know the brand equity of the PHEI. Their interest would lie in the acquisitions of PHEIs by large corporates (local and international) who have been moved into the field of higher education - examples Adcorp, ADvTECH, Educor and Pearson Ltd.

Sponsors (30\%) and corporate HR practitioners (38\%) shows low response rates to the sustainability of PHEIs as, once again, their interest lies in student success in achieving their qualification.

The findings and analysis of Table 1 indicate that, initially, PHEIs were not that well-known amongst major stakeholders. Thus, with the resultant allocation of resources for management to brand and advertise, the value-added branding framework can collectively enhance brand awareness of PHEIs as well as build relationships with stakeholders in order to change public perception of brand identity of private higher education in South Africa. Even though no clear distinction emerged in this area, it was evident, that different stakeholders respond differently to specific branding and subsequent advertising of the brand. Thus, of relevance to the PHEI brand is a differentiated consumer behaviour approach that combines marketing communications of a social media nature for students, and more traditional advertising for parents. The Independent Institute of Education [17] a benchmark for PHEIs, seems to have the mix right, since it has an inter-active website that relate to students, and an awe-inspiring television advertisement that focuses on student success relevant to parents. In addition, their social media reach to students has facilitated many students making enquiries to study at their various private institutions.

Another aspect, emerging from Table 1, was the lack of communication channels (if any) between the PHEI and corporates. The distinct lack of communication between the PHEI and specifically the corporate HR practitioners culminated in poor relationship building between these two parties. This lack of communication with corporate HR practitioners, culminated in poor graduate placements of students from PHEIs. PHEIs need to establish a clear line of communication with corporates.

In addition, Table 1 is indicating a third avenue of input related to the sponsors, both corporate donors and individual financial contributors, who, whilst not prime decision makers in the choice of a PHEI, were not acutely aware of the brand. Whilst, as sponsors, they would abide by the decision of their protégés as to which education institution they wanted to attend. However, they would always be concerned with the brand performance of the PHEI, and how well known the brand was.

A case in point with relevance to the point, raised in the opening paragraph as to the public's lack of knowledge of PHEIs, provided a fourth avenue, pertaining to Table $\mathbf{1}$ and that was the branding of the academic governing body/ holding company of a PHEI. Two examples would be the IIE in the case of Varsity College [18], and Pearson Ltd for CTI College (now renamed Pearson College for Higher Education) [19, 20], which are both well listed and represented on the stock exchange for their shareholders but have little brand recognition amongst the general public. A clear line of synergy should be drawn between promoting the academic governing body institution and the individual brand, bearing in mind that the students spend a majority of their time, relating to the latter on the brand's campus. Brand knowledge of a brand that has a proven track record of success and sustainable brand equity, will attract more students to a specific PHEI. 
As part of the results, obtained from stakeholder interviews, available branding models and frameworks were assessed as well as input from stakeholders in Table 1, in order to determine their suitability to guide the branding of PHEIs. The assessment looked at their suitability, strengths and weaknesses in terms of the branding of PHEIs, thereby providing some of the elements that were adopted in the proposed framework, as indicated in Fig. 1.

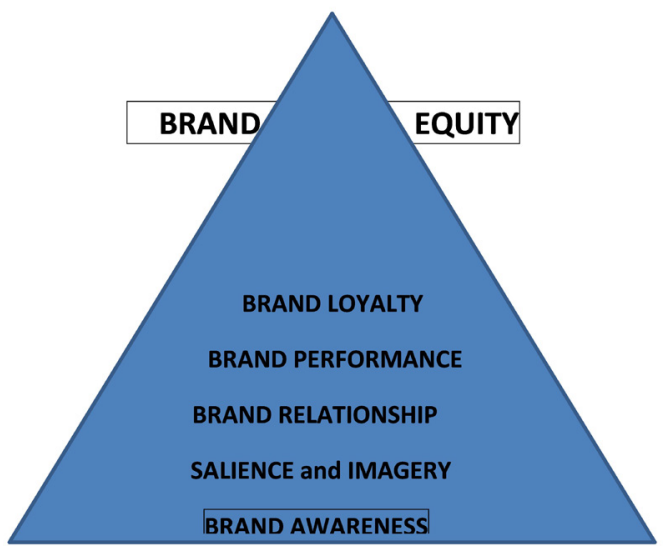

Fig. 1. Elements of the value-added branding model for PHEIs in South Africa (adapted from Keller, [16])

Both Aaker [13] and Keller [16] define brand equity in more holistic terms, which apply to this research article. These two acclaimed authors on brand equity incorporate total value of the brand, including price premium, satisfaction, reliability, brand image, and consumer perceptions. From a PHEI perspective these brand equity attributes were directly applicable to the formulation of the proposed branding model, since the findings indicated that stakeholders will respond to the brand name and brand performance that builds sustainable brand equity, and not consider the brand as a commodity or generic service. One of the most significant aspects of this research article is the knowledge, derived from the two prominent branding models relative to the branding of a PHEI that must nullify this negative perception of an accredited qualification from a PHEI. Thus, the positive consumer-based brand equity, endorsed by both Keller [16] and Aaker [13], is required from a PHEI in order to provide a competitive advantage.

Both the responses from stakeholders and the elements in the figure (above), relating to service reliability and service effectiveness, indicate how important brand performance is to consumers. The sponsors and corporate HR practitioners specifically indicated that the competitive advantage that a brand will show over other brands will relate to the brand performance - service reliability and service effectiveness.

The brand awareness cornerstone of the proposed value-added branding framework provides the brand recognition and brand awareness [13]. The purpose of the proposed branding model is to predict consumer behaviour in the future, which relates to their awareness of the brand.

This study proposed that a value-added branding model for PHEIs to differentiate themselves and create a sustainable competitive advantage for their businesses. This culminated in one of the significant outcomes of the study. The findings and analysis of current branding models showed that, initially, PHEIs were not that well-known amongst major stakeholders. Thus, with the resultant allocation of resources for management to brand and advertise, the value-added branding model, indicated in Fig. 1 (above), can collectively enhance brand awareness of PHEIs as well as build relationships with stakeholders in order to change public perception of brand identity of private higher education in South Africa.

Further analysis of the results provides positive aspects of PHEIs in South Africa, where they are self-funded and need to provide a setting where everyone of students, lecturers and administrators believes their learning environment is advantages in terms of student learning [21]. This concept needs to be transferred into a branding driver for private education institutions. These pri- 
vate institutions in South Africa offer a limited size lecture room for a small, relationship building environment with most class sizes under 50 students. PHEIs have created lecture room spaces that enhance and complement their commitment to student engagement and success. An example of the learning environment created is the Independent Institute of Education (IIE), which is a private higher education institution, operating across 21 campuses, offering more than 90 registered and accredited programmes from Higher Certificate to Masters levels on its Varsity College, Vega and Rosebank college campuses [17]. Furthermore, the IIE commits to student success, which includes a focus on innovative and supportive teaching methodologies, a comprehensive and holistic developmental student support system and the provision of learning opportunities that meets the diverse needs of the student population.

Teaching and Learning as part of classroom didactics is another strength of the private education institution that needs to be both marketed and branded. With a focus on a smaller classroom, the learning environment can be implemented with a focus on a limited number of student participation [22]. To promote a successful Teaching and Learning classroom didactics environment, a Scholarship program proves to be highly innovative. Professor Jonathan Jansen, currently Head of the Faculty of Education at Stellenbosch University, previous Stanford graduate as well as non-executive director of the IIE, proposes that Scholarship is a fundamental purpose of higher education, more likely to be developed at the more demanding intellectual levels of analysis, synthesis, and evaluation specific to a smaller class environment. Scholarship, applied in most PHEIs in South Africa, suggests a scaffolding of learning, so that students develop increasingly subtle and complex abilities [23]. The most basic level describes copying a physical process often with a great degree of active consciousness (imitation) - normally the level of new higher education students. The argument raised is that this Scholarship programme will develop skills amongst students, such as academic writing, gathering and analysing data and most importantly, an attitude and expectation of independent enquiry all skills that will invariably contribute to a student's success in the private environment.

Traditional higher education bases student learning on how many hours are spent in the classroom (reinforced by mandatory, stipulated hours of teaching necessary) and not necessarily how much a student has learned. Mendenhall $[24,25]$ in a paper titled: "Game changers" discusses a new model for Higher Education, called Competency-Based Education (CBE), implemented in many private colleges in South Africa. This concept was specifically motivated for the struggling student who cannot keep up with the rest of the class and who may need more time to learn and master specific concepts. Moreover, the variability of each course within the same degree programme at the same education institution will mean that two students from the same program will not have equal levels of knowledge or competence. Thus, this program, implemented at many private institutions, is based on student's confidence and by demonstrating master of competencies instead of earning credit hours. This programme provides learning communities for limited class sizes [26], wherein students can interact with course mentors and peers to discuss content and post questions - a major branding initiative for PHEIs in South Africa.

Table 2 below, shows an extension of Mendenhall's CBE model that drives student success at private institutions

Table 2

Educator responsibilities at PHEIs

\begin{tabular}{cc}
\hline Traditional Institutional Role & Alternative approach at PHEI \\
\hline Delivery of Instruction & Technology delivers instruction (Transformational digital learning design) \\
Course design & $3^{\text {rd }}$ part curriculum designers \\
$\begin{array}{c}\text { Selecting learning materials } \\
\text { Assessment design }\end{array}$ & $\begin{array}{r}\text { Faculty search to select best online learning resources for teaching didactics and assessments } \\
\text { Content support }\end{array}$ \\
Competencies determined and assessments to measure each competency (C-B L) \\
Subject-specific mentors, available for one-on-one and one-to - group sessions reviewing content \\
Student mentors communicate regularly with students not counsel, advise, coach, organize \\
and motivate remotely or face-to-face.
\end{tabular}

(Source: adapted from Mendenhall [24]: Game changers) 
Problem based learning (PBL) or Inquiry-based learning provides further argument and points towards a strength of PHEIs, in that the Lecturers can implement these learning designs in a small lecture room environment. In PBL students go through an extended process of inquiry in response to a complex question, problem or challenge. While allowing for some degree of student input, projects are carefully planned, managed and assessed to help students learn key academic content, practice $21^{\text {st }}$ Century skills, such as collaboration, communication and technology enhanced participation.

Anne Whaits, National Academic Manager at a large PHEI in South Africa presented a paper on Transformative Digital Learning design in 2016 [27] that provided a new culture of learning relative to PHEIs. This opened up a new learning environment and presented another strength of PHEIs relative to Digital Learning design. Arguably, the modern-day classroom has to be equipped for the digital age in order for the $21^{\text {st }}$ Century school leaver and student to relate to. Thus, in private higher education, technology in the classroom acts as an agent for transformational change in learning design. IBL justifies one such learning design as it applies the components of learning design in learning tasks (projects); learning supports (frameworks and instructivism) and learning resources (web links, case studies, internet). This technology driven learning designs provide opportunity for students to build and evidence their skills of critical thinking, communication, collaboration, and creativity.

Negative aspects of the results of the study is that private colleges in higher education cannot be seen as a real competitor to a private university - that is ultimately the challenge, facing PHEIs and making a focus on providing branding elements based on Keller and Aaker's benchmark model. Christensen \& Eyring [7] wrote in his book: "The Innovative University" that for the first time, disruptive technologies are at work in higher education. For most of their histories, some carrying over 150 years in existence, traditional universities and colleges have had no serious competition except from other universities with similar operating models. Now, though, there are disruptive competitors, offering face-to-face tuition and online courses. Many of these institutions operate as for-profit entities, emphasizing marketable degrees for both school leaver and working adult. Traditional colleges and universities have valuable qualities and capacities that can offset those disruptor's advantages - but not for everyone who aspires to higher education and not without real innovation. Christensen \& Eyring [7] go on to discuss three factors that resolved the anomaly of traditional universities in so called decline. Firstly, teaching was difficult to disrupt as its human qualities could not be replicated. However, the argument posed that one of the strengths of a PHEI lies in technology with a transformative digital learning design does not hold with this point. A digital learning design, utilised by most PHEIs, does not do away with the human element - it in fact complements it. Secondly, observation and perceptions are indicating that the campus experience is central to a student's university experience. One must concede that this would be very difficult to emulate from a private education perspective and is considered a major challenge for any private institution. Large campuses with sports fields, auditoriums, halls, amphitheaters are not part of the learning landscape for any PHEI. Arguably, the strength of private institutions is confined to small, intimate campuses, yet it does not provide the campus life of a large sprawling traditional university. And the third reason why higher education has seen many new entrants not only in South Africa, but worldwide, is alumni and state financial backing, the downfall of private education. Alumni and state support gives traditional universities and colleges staying power, unique to higher education. Traditionalism of some public university's dates back over 150 years, which has allowed the institution to build a mantra that carries forth in generation to generation, parent to child. The fledging state of private higher education does not allow for this traditionalism and becomes a challenge in the recruitment of the wealth of new entrants and school leavers, wanting to study at a university.

De Vos \& Strydom [28] in the "New Learning Revolution" state that in a higher education landscape the general goal is to move up, grow and develop, notwithstanding the high cost of doing so. De Vos \& Strydom [28] cite the example of Harvard University Business School, dean Kim Clark, no less, citing the difficulty of simultaneously raising the school's quality, decreasing its costs, and serving more students. Among other things, this meant becoming more selective 
in admissions (looking at student's/ parent's financials before admission!), bolstering the faculty's research and publication quality and quantity to enhance the program's reputation in the eyes of other academic leaders - crucial initiatives and expensive ones, requiring fueling and input from federal (state) research grants and student subsidies per registration. A challenge for PHEIs in South Africa and more is a catch-22 situation where faculty's research and facilities programs need continuous upgrading and development in order to maintain accreditation of their qualifications, cannot be done as they are self-sufficient with no state grants or subsidies. Lack of research facilities at most PHEIs in South Africa is indicative of the status they have as universities. Currently the CHE only recognises one private higher education institution as a university - Monash University, situated in Johannesburg. In addition, to highly accredited programme offerings and a diversity of subject choices, Monash University has a fully-fledged research faculty, where post graduate students can research and produce articles for publication - a major downfall of the remaining private colleges in South Africa.

\section{Limitations of the study}

In order to ascertain limitations of the study one would need to benchmark the South African PHEI environment against International private education standards to ascertain the limitations. Ghauri and Cateora [29] provided shared or common traits concerning the development and growth of PHEIs in these emerging economies. In the South African context, these traits have been met by private higher education, as indicated in the rapid growth of PHEIs discussed above. These traits include:

- Providing potential for significant growth;

- Undertaking programmes of significant reform, specifically concerning qualification diversity and accreditation;

- Have regional economic drivers, indicative of the national footprint of PHEIs throughout South Africa; and

- Will have further expansion into neighbouring markets (Southern Africa) as the South African PHEIs grow and develop.

South Africa's emerging markets meet all of the above traits, whilst firmly establishing itself as one of the top ten big emerging markets (BEM) worldwide. At the same time these traits are consistent with the phenomenal growth of private higher education providers in South Africa. According to Nair [30], sustaining brands in emerging markets is every bit as intricate and complex as developed countries. One of the areas of emerging markets that requires additional knowledge and input is the traditional communication channel(s) that marketers utilise to advertise and promote their brands, which, based on accessibility from the market place, should be innovative and needs-oriented. Atsmon [31] further indicates that both developed markets and emerging markets currently use technology to develop the possibility of increasingly deep consumer engagement at each phase of the decision-making spectrum. This spectrum is identified as four critical areas, which is critical when a student or a parent makes the choice of studying at a private education institution that can either gain or lose consumers. The areas are presented below:

- When a consumer first decides to utilise a service and considers a few brands;

- Active evaluation, when a consumer researches a potential service;

- When the consumer selects a brand at the moment of brand selection; and

- When the consumer experiences service selected - post decision.

Thus, the sustainability of a PHEI in South Africa, an emerging market and economy, needs to be seen in the light of the above four factors when making a choice to study at any one of these higher education institutions. At the same time, the education institutions need to take these factors into consideration when branding the specific PHEI - a potential limitation of the study

Brazil, Russia, India, China and South Africa (BRICS), an international trading bloc of countries, is based on three categories of economies, namely:

- Innovation-driven economies - developed or highly competitive countries with advanced economies and excellent infrastructure.

- Efficiency-driven economies - low to medium income countries, including BRICS countries; and 
- Factor-driven economies - low-income countries, such as Iran, Egypt, Angola and Pakistan - developing countries [16].

Table 3 below provides a comparison of both developed countries and emerging market economies with reference to infrastructure, lifestyle goods (television sets and cell phones), and basic services (water and electricity).

Table 3

Infrastructure of selected countries ( $1^{\text {st }}$ world and emerging) in units/ 1000 (users)

\begin{tabular}{cccccccc}
\hline Country & $\begin{array}{c}\text { Roads (per } \\
\text { 1000 people) }\end{array}$ & $\begin{array}{c}\text { Vehicles (per } \\
\mathbf{1 0 0 0} \text { people) }\end{array}$ & $\begin{array}{c}\text { Electri- } \\
\text { cal power } \\
\text { (KWH) }\end{array}$ & $\begin{array}{c}\text { Mobile } \\
\text { phones (per } \\
\mathbf{1 0 0 0} \text { people) }\end{array}$ & $\begin{array}{c}\text { PC's (per } \\
\mathbf{1 0 0 0} \text { people) }\end{array}$ & $\begin{array}{c}\text { Colour TV } \\
\text { (per 100 } \\
\text { houses) }\end{array}$ & $\begin{array}{c}\text { Shower (per } \\
\mathbf{1 0 0} \text { house- } \\
\text { holds) }\end{array}$ \\
\hline USA & 6304 & 859 & 12183 & 723 & 731 & 99 & 99 \\
Brazil & 1724 & 79 & 1776 & 464 & 167 & 86 & 75 \\
China & 1765 & 223 & 987 & 734 & 255 & 65 & 63 \\
Germany & 6104 & 729 & 6046 & 785 & 625 & 92 & 97 \\
India & 3315 & 120 & 380 & 146 & 185 & 42 & 41 \\
Kenya & 64 & 110 & 120 & 112 & 55 & 46 & 43 \\
South Africa & 476 & 143 & 3860 & 909 & 255 & 56 & 71
\end{tabular}

(Adapted from Ghaum [32]; updated 2018).

The above table illustrates the differences in both economy and infrastructure for both first world and emerging markets worldwide. The noticeable differences occur in transport and technology, as well as media access. The importance of the disparity in cell phones per 1000 users versus access to a computer (255 users per 1000 in South Africa) showed, for the purpose of this article, an impact on the ability to sustain a private education organisation in the midst of basic needs and necessities as well as technology needs, necessary for a PHEI to function. Thus, this comparative table indicates that a sophisticated marketing programme that includes branding for specific markets still requires meaningful contribution from the organisation to both reach the consumer and ensure economic success and growth, which are vital for PHEIs in emerging markets.

Thus, it is evident from the classification above that South Africa, as an emerging economy, competes with fast developing countries, and yet finds itself part of both southern Africa and Africa, consisting of more factor-driven economies with untold health, housing, and other socio-economic problems. The emerging market concept is hence a limiting factor to sustain an institution, specifically for the branding of the South African PHE sector.

South African PHEIs in International context - a prospect for future research

Globalisation can provide an important benefit of a uniform international image [29] to a PHEI in South Africa, which can enhance its status as an institution, as well as provide an internationally recognised qualification - a perception that bears reality for education institutions in South Africa. Even though the foundation for this study was based on analysing current branding models and perceptions of an accepted, suitably accredited qualification from a PHEI, globalisation can also provide a future branding context for this research article.

A global company engages in global marketing activities and markets itself worldwide [33]. This equates to an organization, considering significant market segments with the same or similar demands for the same product/service worldwide. In addition to current branding models, PHEIs in South Africa can benchmark its education institution and qualifications against the local market on a global scale as means to measure its success rate on an international level. For example, the Open University in Milton-On-Keynes in the United Kingdom has 250000 students with registrations spanning 80 countries outside of the United Kingdom [34]. Thus, the benefit of a global market orientation for PHEIs in South Africa would be to understand the norms that are measured, and the operational actions that are implemented, as well as marketing strategies, which are used from an international education institution, to implement a future branding model locally.

In discussing the current state of PHEIs in South Africa, a comparison to other international private education institutions will provide a window to research, albeit in a limited way, the prog- 
ress, made by these PHEIs. Two such comparisons, one from an emerging economy, Brazil and Asia can be included in a future study.

From 1996 the Ministry of Education in Brazil relaxed regulations on colleges, offering private tuition throughout the country. Prior to this period, higher education could only be provided by public universities and non-profit organizations, such as religious institutions [35]. As a result of this deregulation, private colleges and universities have escalated significantly in the growth of their facilities and number of students. This growth period has seen mergers and take-overs occurring, with distance learning in Brazil, becoming predominantly private and attracting over 120000 students, whilst showing bottom-line earnings in excess of US 1.5 billion dollars [35]. According to Goodson [36], Brazil has experienced phenomenal growth in the private education sector. A comparative analysis between South Africa and Brazil's PHEIs would draw many similarities, attributed to commonality in emerging economies. Much like the South African private education landscape, these similarities relate to the phenomenal growth that PHEIs experienced in both countries, yet are also similar in the challenges that they faced. For one, a lack of infrastructure investment, as well as a lack of well-equipped laboratories and facilities, are similar challenges. Magadza [37] documented these challenges, stating that none of the Brazilian private higher institutions have research facilities, much like the lack of facilities in South Africa. This dramatic growth in the private providers in Brazil is endorsed by McCowan [38] who discussed the World Bank involvement in Brazil private higher education, promoting this expansion based on the private providers' ability to ensure rapid increase in enrolments (performance). This growth of private higher education in Brazil can have implications for both sustainability and quality in any future research on comparison to PHEIs in South Africa.

These factors remain generic to most PHEIs worldwide and are certainly applicable to the South African environment specifically from the measurement of quality of education, from both the higher education's institution's point of view and industry standards. Another area of research could be the rise and growth of PHEIs in Brazil over the last decade. One aspect, coming out of this period, was the merger between government and industry that sparked interest by the Brazilian government concerning the importance of technology, offered by private institutions in the formulation of the Brazilian General Command of Aerospace Technology (CTA) [35].

This aspect can be of interest to future research, as a government partnership with a private education institution can develop to areas in South Africa, including technology and education, considering the skills shortage of trained teachers in South Africa. This would both assist the PHEI financially (sustainability) and provide employment to trained teachers who work after graduating from government schools - in terms of having a well-recognised and sustainable PHEI that has government backing to address the critical skill shortage of, for example, qualified teachers in South Africa.

Another emerging economy from the majority of developing countries in Asia showed that legislation that allows the privatisation of higher education institutions only came into being in the late 1990s [39]. This allowed two aspects to develop; firstly, the introduction of tuition and fees and, secondly, allowing special and executive programs to be offered [40].

If legislation is relaxed, it can indicate a turnaround in the growth of private education institutions as a basis for future research. In contrast, this caused more of a "spotlight" effect with these institutions, coming under government scrutiny (article from Asian Development Bank, [40]. The article further postulates that a lack of funding from government, as well as low student enrolment, ensured a lack of demand for private higher education in most parts of Asia - that can provide similarities with the South African higher education footprint. At the same time, a lack of ability from private academic institutions to balance the marketing role (branding) and quality academic service delivery, can in the long term also contribute to this lack of demand.

Asian PHEIs provide useful insight into the majority of their developing countries' similarities to the South African private education environment. Despite the growing number of high school graduates who look to higher education institutions in Asia, a lack of government funding of private institutions leads to a lesser demand for private education in Asia than South Africa. 
Brazil and Asia in terms of their current status, funding, qualification accreditation, legislation and branding of their private education colleges can provide a basis for future research to ascertain alignment with the South African private education landscape.

\section{Conclusion}

The results are indicating the strengths of PHEIs in South Africa can, at face value, be negated by the challenges facing private colleges - funding being one of the major one's. As indicated previously, most of the PHEIs in South Africa have a corporate identity and all the larger ones are part of a large conglomerate. This renders these private institutions profit driven and, in addition to answering to students, have other stakeholders to account for. The major strength, described above, is the classroom didactics delivery and learning environments created that meet the student requirement of academic success. Once a PHEI can find its niche market and serve the right demographic of student within a certain close proximity location, this strength and brand needs to be advertised. PHEIs need to differentiate themselves and create a sustainable competitive advantage for their businesses.

This study is alluding to the fact that a value-added branding framework can enhance the awareness and positive perceptions of a PHEI that can improve the long-term stakeholder value of the brand. Taking the above into consideration, a subsequent generic model, aligned with the analysis of the two prominent branding models of Keller [12] and Aaker [13], was formulated for PHEIs in South Africa.

Should this occur, PHEIs in South Africa will no longer have to undergo scrutiny of their qualifications in terms of them being local or internationally accredited. PHEIs, although not having the tenure or traditionalism of a public university, will be able to advertise academic success, stronger support, innovative and technologically-enhanced classroom and lecture didactics, professionalism, and relationship building with stakeholders owing to their smaller and more controlled environments. They need to know thoroughly how to reach these stakeholders to advertise these drivers of PHEIs.

With public universities, closing their doors to countless applications that they cannot accommodate owing to, firstly, high levels of students, wanting to study at tertiary institutions and, secondly, capacity issues at universities, the South African education landscape needs the footprint of Private Higher Education Institutions (PHEIs). This will be of mutual benefit to government, as well as public and private education.

\section{References}

[1] Badenhorst, A. J. (2019). This is how South Africa can handle the growing demand for Higher Education. Available at: https:// www.usb.ac.za/usb_insights/this-is-how-south-africa-can-handle-the-growing-demand-for-higher-education/

[2] Council on Higher Education: South Africa (2020). Register of Private Higher Education Institutions.

[3] Seehole, C. (2001). Higher Education reviewed - Council on Higher Education. 21-25.

[4] Cloete, N., Maassen, P., Fehnel, R., Moja, T., Gibbon, T., Perold, H. (Eds.) (2006). Transformation in Higher Education. Amsterdam: Springer Publishers. doi: http://doi.org/10.1007/1-4020-4006-7

[5] Froneman, L. (2002). Private Higher Educational Institutions in a changing South African environment. Acta Commercii, 2 (1). doi: http://doi.org/10.4102/ac.v2i1.22

[6] Mabelebele, J. (2015). HE in South Africa: emerging challenges and implications for universities. Paper presented at HE conference. University of Limpopo. Available at: https://www.pwc.co.za/en/assets/pdf/he-conference_the-future-of-higher-education-in-south-africa.pdf

[7] Christensen, S., Eyring, H. (2014). The innovative university - changing the DNA of Higher Education from the inside out. San Francisco: Wiley \& sons, 512.

[8] Bitzer, E. (2002). South African legislation on limiting private and foreign higher education: protecting the public or ignoring globalization? South African Journal of Higher Education, 16 (1). doi: http://doi.org/10.4314/sajhe.v16i1.25268

[9] MacGregor, K. (2008). South Africa: Private higher education stabilises. Available at: http:/www.universityworldnews.com/ article.php?story=20080509083546518 Last accessed: 17.06 .2019

[10] Altbach, P. G. (2005). The Private Higher Education Revolution: An introduction. Amsterdam: Sense Publishers. doi: http:// doi.org/10.1163/9789087901035_002 
[11] Olonisakin, F. (2013). Lessons and challenges for education in Africa. Available at: https://www.universityworldnews.com/ post.php?story=20130831103013523

[12] Keller, K. L. (2013). Strategic Brand Management: Building, measuring and managing brand equity. New Jersey: Pearson Education, 608 .

[13] Aaker, D. A., Joachimsthaler, E. (2009). Brand Leadership. London: Simon \& Schuster.

[14] Aaker, D. A. (2008). Strategic Marketing Management. New York: John Wiley.

[15] Neal, W., Strauss, R. (2008). Value Creation- the power of brand equity. Ohio: Cengage Learning, 368.

[16] Cravens, D. W., Piercy, N. (Eds.) (2012). Strategic Marketing. New York: McGraw-Hill Education.

[17] Independent Institute of Education (IIE) (2019). Private Higher Education Institution. Available at: https://www.iie.ac.za/ Last accessed: 21.08.2020

[18] Varsity College. 2019. Prospectus 2019. In Untitled (Online). Available at: https://www.varsitycollege.co.za/

[19] CTI. 2019. Prospectus. Available at: http://atimumbai.gov.in/parent/pdfs/cits \%20admission-2019-20.pdf

[20] Bond University. Available at: https://bond.edu.au/ Last accessed: 21.11.2019

[21] Kuh, G. D., Kinzie, J., Schuh, J. H., Whitt, E. J. (2010). Student success in College. Creating conditions that matter. Washington: Jossey- Bass publishing, 416.

[22] Ramdass, K. Kruger, D. (2012). The challenges facing Higher Education in South Africa. Paper presented at University of Johannesburg. Higher education conference.

[23] Jansen, J. (2019). Education that matters. Available at: https://ed.Stanford.edu/alumni/jjansen Last accessed: 03.03 .2021

[24] Mendenhall, R. (2016). Game Changers. Paper presented at HE conference. Cape Town.

[25] Monash University. Available at: https://www.monash.edu/

[26] Fry, H., Ketteridge, S., Marshall, S. (2009). A handbook for Teaching and Learning in Higher Education. London: Routledge.

[27] Waits, A. (2016). Transformational Digital Learning. Paper presented at Varsity College Conference on Higher education.

[28] De Vos, A. S., Strydom, H. (2013). Research at Grass Roots. Game Changers. Pretoria: Van Schaik.

[29] Ghauri, P. N., Cateora, P. (2010). International Marketing. Berkshire: McGraw- Hill.

[30] Nair, E. T. (2010). Emerging markets: The future. Harvard Business Review, 21.

[31] Atsmon, R. (2012). Marketing Emerging Markets. Chicago: Thompson Learning.

[32] Ghaum, S. (2018). The making of Kabhi Khushi. New Delhi: Routledge.

[33] Cateora, P. R., Gilly, M. C., Graham, J. L. (2010). International Marketing. Singapore: McGraw-Hill Education, 659.

[34] Open University. (2019). Prospectus. Available at: http://www.openuniversity.edu/

[35] MacGregor, K. (2016). Brazil: Private education far better than none at all. Available at: https://www.universityworldnews. com/page.php?page $=U W_{-}$Main

[36] Goodson, S. (2015). Why brand building is important. Available at: https://www.forbes.com/sites/marketshare/2012/05/27/ why-brand-building-is-important/?sh=4e4836633006 Last accessed: 10.01.2021

[37] Magadza, M. (2013). Wake up call for the higher Education sector. Available at: https://www.universityworldnews.com/post. php?story=20131128172631434

[38] McCowan, T. (2019). The growth of private higher education in Brazil: implications for issues of equity, quality and public benefit. Education Policy Analysis Archives, 13, 27. doi: http://doi.org/10.14507/epaa.v13n27.2005

[39] Chealy, C. (2006). Higher Education in South- East Asia. Bangkok: UNESCO Bangkok, 254.

[40] Asian Development Bank (2012). Paper titled: Private Higher Education across Asia: Expanding Access. Searching for quality. Available at: https://www.adb.org/sites/default/files/publication/29869/private-higher-education-across-asia.pdf

How to cite. Bird, A., Mugobo, V. (2021). Branding private higher education institutions in South Africa through the evaluation of current branding models. EUREKA: Social and Humanities, 3, 15-27. doi: http://doi.org/10.21303/2504-5571.2021.001841 